\title{
UNDERSTUDIES' AND INSTRUCTORS VOICES OF THE TALKING ASSESSMENT IN INDONESIA
}

\author{
Alexander Musa \\ alexandermusa69@gmail.com
}

\begin{abstract}
In school, instructors have huge influence in reviewing talking limit since the incredible impact examination will be impact on students improvement, educators should have the data and appreciation concerning what they asses, how they asses and assemble the data of students to get the convincing assessment from understudies. The researcher will use interview to know both perspective on understudies and instructor toward the assessment of talking and the students understanding toward the activities/task that given by educators in talking class. Besides, the examiner will see the class, stressed with respect to how the educators asses understudies talking capacity. What method the instructor use and concern the examination instructive arrangement 2013. What's more it in like manner concern what kind of attempted the teacher use in the homeroom to inspire understudies talking ability. Furthermore, the researcher will record the development associated with talking in class. There are some record moreover will be assembled in this assessment like the material of talking class, and association talking examination from educators.
\end{abstract}

Keywords: Talking assessment, understudies' voice, instructors' voice

\section{Foundation}

Conveying in is seen by language analyzers as the most problematic of the four language capacities to overview. Looking over talking expects that we either notice a "live" oral execution or that we get the display by specific means for appraisal soon. A method for elicitation ought to be picked, rating scales ought to be made, and examiners as well as raters ought to be ready (Marzuki, 2016; Fatimah and Santiana, 2017; Alek et al., 2020a; Marzuki and Kuliahana, 2021; Santiana et al., 2021).

In school, teachers have huge impact in looking over talking limit since the extraordinary impact examination will be impact on students improvement, educator should have the data and perception concerning what they asses, how they asses and accumulate the data of students to get the convincing assessment from student. In any case, talking assessment is bothersome in light of the fact that a few minutes' talking evidence isn't satisfactory to condemn an understudy's capacity (Waugh and Joliffe, 2008). It is attempting to overview talking, by virtue of the different factors that sway the way wherein teachers survey oral ability. Parts that are considered ordinarily critical fuse stress, accentuation, language, goofs and the ability to use language fittingly to speak (Richards, 2008; Bora, 2012; Marzuki, 2017; Thuy and Nga, 2018; Santiana et al., 2021).

There are something like three test that looked by teachers in talking examination, saving a couple of moments, picking the assessment activities and concluding appraisal rules. The educator ought to expect evaluation, notice the students, and record their presentation. 
Meanwhile, to complete the improvement in talking, the student input in talking examination is also required. For the present circumstance the perspective on students toward talking assessment concerning the task of examination that instructor use is critical. Acumen is the manner by which overhauls are picked and collected by an individual with the goal that the upgrades can be really unraveled. As proposed by Kleinke (1978), understanding can affect students' achievement in learning language. Subsequently, there is association among acumen and acknowledging which happens among the students in talking class. At the point when the students fathom the things they see stressed of instructors' task that given by them, and they have positive information they will be really in talking class. Inaddition the perspective on students similarly will deal with the shortfall of task or development from teacher. Likewise, educators know how to deal with their picked endeavor or activities in talking class. Appropriately, the talking evaluation really captivating to explore, stressed from two side perspective on teacher and student.

Taking a gander at talking evaluation, it can't be detached from instructive arrangement. The most state-of-the-art instructive program that embraced in Indonesia is 2013 instructive arrangement. Considering that rule, in the beginning of 2013, The Ministry of National Education of Indonesian Government arranged one more instructive arrangement for the simple until senior auxiliary schools named as Curriculum 2013. As the affirmation of the public power, Curriculum 2013 is an adjustment of the past instructive arrangement, Curriculum 2006 or KTSP. There are a couple of materials added to Curriculum 2013 which are not presented in Curriculum 2006, and moreover there are a couple of materials killed from Curriculum 2013 which are presented in Curriculum 2006. As described in Regulation of Republic Indonesia No. 66 Year 2013 with respect to Education Assessment Standards, Curriculum 2013 is using genuine assessments, self-evaluation, portfolio examination, formative examination, and summative assessment.(Natalia:2015)

With the ultimate objective of discussion, there are a couple of assessments that had been driven concerning talking examination. widhiayu (2018) research students' understanding on the use of video to study students' presentations in Public Speaking class. This study base visible of students of the usage video transparently talking. Regardless, the concentrate essentially revolves around the public talking class and the impression of students' in the survey, the use of instructors' knowledge has not been explored in the audit. Thus, it is vital for research the teachers' understanding in the momentum audit, in light of the fact that the perspective from instructor similarly can cause the peruser to fathom whether or not there is progress when teacher use video.

Another audit coordinated by Thuy (2018), the survey examined EFL teachers' impression of in-class English talking evaluation. The forms of teachers' bits of knowledge inspected in the energy research fused their general cognizance of talking examination, the task sorts of in-class talking assessment, and the instructors' work related with the evaluation execution. This focus on base on the general cognizance of talking assessment without including the instructive arrangement that at this point use. In like manner, in the current survey, it is fundamental to 
inspect the talking examination with teacher perspective and the assessment associated with instructive program.

Hence, in the current audit, the expert will use the part from proficient school and use acumen from both side teachers' and students' knowledge. There are some characteristic of focus in this assessment specifically kind of talking assessment that used by teacher, the educator impression of talking evaluation considering instructive program 2013, the students perspective on talking examination stressed of undertaking types that given by teachers in talking class. The survey will used gathering, insight and documentation as instrument of assessment.

\section{Techniques}

The researcher will use interview to know both perspective on student and teacher toward the assessment of talking and the students understanding toward the activities/task that given by educator in talking class. Also, the examiner will see the class, stressed with respect to how the teacher asses student talking capacity. What procedure the teacher use and concern the evaluation instructive arrangement 2013. What's more it moreover concern what kind of embraced the teacher use in the homeroom to summon student talking ability. Furthermore, the researcher will record the development associated with talking in class. There are some record moreover will be accumulated in this assessment like the material of talking class, and association talking examination from teacher.

\section{Writing Review}

As a valuable skill, talking is meandered aimlessly among various subject matter experts. The strength of talking capacities is viewed as a requirement for most EFL and ESL understudies (Richards, 2008, p. 19; Florez, 1999). While attempting to portray speaking, Richards (2006) fights for the "ordinary 'language use" which occurs "when a speaker takes an interest in critical affiliation and stays aware of fathomable and advancing correspondence despite limitations in their open ability" (p. 14). Richards' significance of talking resonations the interactional piece of language that is used to fuel social intercourse (Yule, 1989, p. 169), to propel ability to comprehend individuals on a more profound level (Bora, 2012), to fulfill explicit goals or to pass on explicit contemplations, assumptions, needs, tendencies, or opinions. Another acumen comes from Thornbury (2005: iv). He describes talking as an instinctive cooperation which requires the ability to take part in the organization of talking turns. Meanwhile, Byrne (1997: 8) in Liao (2009) tells that talking or oral correspondence is a two-way process among speakers and crowd individuals which incorporates the valuable capacity of talking and open aptitude of perception (or tuning in with appreciation).

Therefore, talking is imperative and talking as well as including understanding and a couple of elements that sway a singular's talking limit. As demonstrated by Kingen (2000), talking fulfills the going with twelve limits:

1). Personal - conveying individual opinions, sentiments, convictions and considerations.

2). Descriptive-portraying someone or something, certified or imagined.

3). Narrative - making and recapping stories or successively sequenced events.

4). Instructive - giving rules or giving course planned to convey an outcome. 
5). Questioning - presenting requests to procure information.

6). Comparative - checking out least two articles, people, contemplations, or ends to settle on choices about them.

7). Imaginative - conveying mental pictures of people, spots, events, and articles.

8). Predictive-expecting possible future events.

9). Interpretative - exploring suggestions, offering hypothetical lenient gestures, and contemplating surmisings.

10). Strong - changing others' viewpoints, attitudes, or points of view, or influencing the direct of others some way or another or another.

11). Coherent - explaining, clarifying, and supporting considerations and ends.

12). Informational - offering information to others.

According to a couple of experts' perspectives about talking and conversational limits, students are relied upon to have the choice to use a part of the supporting responsibilities of information, authority of language, movement of contemplations with the objective that this message can be passed on well by crowd individuals or perusers. Moreover, various researchers have inspected qualities talking as not exactly equivalent to other huge scope English capacities. additionally has been explained over the talking limit. considering the limit and talking sway on student knowledge, teacher examination fundamentally impacts the level of student ability and what the students input.

According to Dorobat's explanation (2007: 2), instructors' assessment insinuates a variety of courses in social event information on understudy's ability or achievement by considering on perspectives or pointers that will be taken note. This suggests that teachers can apply various techniques to overview students' talking limits. To find their social capacities considering their program, instructors should design talking assessment practices since it is their commitment to control student progress.

There are a couple of talking practices that can be used. According to Brown (2004), there are a couple of fundamental sorts of talking and its technique of examination. They are according to the accompanying:

1. Imitative

It is the ability to imitate a word, articulation, or a sentence. In this sort, the enlightening capacity of the language isn't key so that test takers don't need to grasp or give meaning or to participate in a shrewd conversation. It infers that the students base on enunciation in spite of the way that accentuation similarly shares as the scoring norms. There are a couple of activities that should be feasible to assess students' talking limit considering this imitative sort. They are word overt repetitiveness task, phone finish evaluation, reiterate sentences.

2. Intensive

This sort of talking doesn't highlight on rhetoric. It more focus on the significance than the respond of the primary speaker. To have the choice to respond well the students need to comprehend the significance even they have unimportant participation with the teachers or their friens as the conversationalists in the conversation. Occurrences of heightened evaluation 
endeavors join facilitated response tasks, examining resoundingly, sentence and trade getting done, Limited picture-flagged tasks. While O'Malley (1996: 79) communicated that picture flagged depictions or stories assessment strategy can be used for individual and beginning or center student. The educator should design grouping of high difference or concealed pictures or photograph. The photographs should be appropriate for age level of the students.

\section{Responsive}

Responsive assessment endeavors incorporate the association of essential two unique ways correspondence and test understanding like incredibly short conversations, standard great news and relaxed discussion, clear requests and comments, etc Since the realness of conversation is critical, thusly the test takers should talk or respond in a flash. There are some evaluation strategies that should be feasible to overview students' talking limit considering this responsive kind. They are $\mathrm{Q}$ and $\mathrm{A}$, give direction and direction, summing up, Test of Spoken English (TSE).

\section{Interactive}

In instinctive talking, the multifaceted design of association can be occurred. It is in light of the fact that the relationship in talking has purposes to exchange information and keep social associations, thusly there should be various individuals drawn in with the conversation. Some assessment techniques considering this astute sort are according to the accompanying; first task is interview, O'malley (1996: 78) acknowledged that oral gathering can be coordinated for all level of language understudies by individual student or in pairs. Second endeavor is imagine. Third are discussions and conversations. Fourth are games. Fifth is oral capacity interview (OPI).

\section{Extensive (discourse)}

It could be said that in this kind of talking has a confined lift from the crowd individuals. Expansive oral creation tasks join talks, oral presentations, and describing. Ordinarily, the language used is in legitimate style, it also organized well preceding playing out the wide talking.

O'Malley (1996: 61) communicated that assessment of oral language should focus in on a student's ability to interpret and convey importance for authentic purposes in savvy setting. It should fuse both commonality and precision. To make a talking assessment, the teachers should zero in on the targets and objectives of study corridor direction before including instructive activities for the evaluation. They moreover need to stress on the ability level of the students. Thusly, the instructors need to ponder the inspiration driving the assessment activity, the typical presentation and the models of every task. Then, they should design a scoring rubric, rating scale, or plan considering the action levels of execution (O'Malley: 1996, p.65). For model rubric or scale, it will fuse open effect or general fathomability, language construction, and verbalization.

In scoring rubric, the teachers should place estimates how the students can treat light of their level of ability. Directly following arranging a scoring rubric, rating scale or plan, they need to set standards of oral language execution. To set them, they should conclude the arrive at score and the portrayal proportions of execution considering every level of ability on scoring rubric. 
Then, the principles should be appropriate to the language learning objections in every level of ability. The students' display in like manner can be a screen of students' progression in showing learning association and selections of students' position.

O'malley (1996: 66-67) explained that there are two sorts of scoring rubrics for talking assessment. Those are extensive and logical scales. Expecting the teachers use a complete scale, they simply need three to six levels of execution. Then, they need to make the rating that fits to the students' genuine display eagerly considering the way that a couple of students may be not fit constantly with some class. Expecting the educators use a quick scale to assess students' talking execution, they need to zero in on students' fortitude and necessities.

\section{REFERENCES}

Albana, H. H., Marzuki, A. G., Alek, A., \& Hidayat, D. N. (2020). Cohesive Devices in Student's Writing (A Discourse Analysis on Argumentative Text). Jurnal Pendidikan Humaniora, 8(1), 6-11.

Alek, A., Marzuki, A. G., Farkhan, M., \& Deni, R. (2020). Self-Assessment in Exploring EFL Students' Speaking Skill. Al-Ta lim Journal, 27(2), 208-214.

Alek, A., Marzuki, A. G., Farkhan, M., Surahman, D., Daryanto, D., \& Febrianto, S. (2020). Computer Based Testing in Senior High School on National Examination. Indonesian Journal of Learning Education and Counseling, 2(2), 204-210.

Ary, D. Jacobs, Sorensen \& Razaviceh, A. (2010). Introduction to Research Education., US : Thomson Wadsworth inc.

Bora, F, D. (2012). The impact of emotional intelligence on developing speaking skills: From brain-based perspective. Procedia-Social and Behavioural Sciences, 46, 2094-2098. https://doi.org/10.1016/j.sbspro.2012.05.434

Brown, H.D. (2004). Language Assessment: Principles and Classroom Practices. Longman.

Cahyadi, A. (2020). COVID-19 Outbreak and New Normal Teaching in Higher Education: Empirical Resolve from Islamic Universities in Indonesia. Dinamika Ilmu, 20(2), 255-266.

Cirocki, A., \& Farrell, T. S. (2019). Professional development of secondary school EFL teachers: Voices from Indonesia. System, 85, 102111.

Dorobat, Dumitru. (2007). The Methodology of Evaluation and Testing. Ministerul Educaţiei şi Cercetării Proiectul pentru Învăţământul Rural.

Fatimah, A. S., \& Santiana, S. (2017). Teaching in $21^{\text {st }}$ century: Students-teachers' perceptions of technology use in the classroom. Script Journal: Journal of Linguistic and English Teaching, 2(2), 125.

Fatimah, A. S., Santiana, S., \& Saputra, Y. (2019). Digital Comic: An Innovation of Using Toondoo as Media Technology for Teaching English Short Story. English Review: Journal of English Education, 7(2), 101-108.

Ghinter,A.Assessment of Speaking,(2013), Acessed on https:// www.researchgate.net / publication/277707664. Retrieved : May $5^{\text {th }}, 2019$ 
Julia, J., Hakim, A., \& Fadlilah, A. (2019). Shifting Primary School Teachers' Understanding of Songs Teaching Methods: An Action Research Study in Indonesia. International Journal of Education and Practice, 7(3), 158-167.

Kingen, S. (2000). Teaching Language Arts in Middle Schools.: Connecting and Communicating. New Jersey: Lawrence Erlbaum Associates, Publishers.

Kuliahana, A., \& Marzuki, A. G. (2020). Repetition Technique in an EFL Speaking Class in Islamic Higher Education in Indonesia. Academic Journal Perspective: Education, Language, and Literature, 8(1), 20-28.

Marzuki, A. G. (2019). The Roles of School Principal Leadership in Developing English Teachers' Creativities in Palu. Al-Ta lim Journal, 26(3), 267-279.

Marzuki, A. G., \& Kuliahana, A. (2021). Using Language Games to Enhance EFL Students' Speaking Skill in Indonesia. Al-Ta lim Journal, 28(3), 213-222.

Marzuki, A. G., Alim, N., \& Wekke, I. S. (2018). Improving the reading comprehension through cognitive reading strategies in language class of coastal area in indonesia. In IOP Conference Series: Earth and Environmental Science, 156(1), 012050). IOP Publishing.

Marzuki, A.G. (2016). Utilizing cooperative learning in islamic college students' classroom, IJEE (Indonesian Journal of English Education), 3(2), 123-139.

Marzuki, A.G. (2017). Developing speaking skill through oral report in an efl class in indonesia, Al-Ta'lim Journal, 24(3), 243-254.

Muazza, M., Mukminin, A., Habibi, A., Hidayat, M., \& Abidin, A. (2018). Education in Indonesian islamic boarding schools: Voices on curriculum and radicalism, teacher, and facilities. Islamic Quarterly, 62(4), 507-536.

Mukminin, A., Eddy, H., Makmur, M., Failasofah, F., Fajaryani, N., \& Thabran, Y. (2013). The achievement ideology and top-down national standardized exam policy in Indonesia: Voices from local English teachers. Turkish Online Journal of Qualitative Inquiry, 4(4), 19-38.

Natatlia, D .K, (2015). Assessment Techniques Used in the English Classes Based on Curriculum 2013. VNU Journal of Foreign Studies. 34(2).

Richards, J. C. (2006). Communicative Language Teaching Today. New York: Cambridge University Press.

Richards, J. C. (2008). Teaching listening and speaking: From theory to practice. Cambridge: Cambridge University Press.

Safriyani, R., \& Khasanah, S. U. (2021). The strengths and pitfalls of Edmodo to Indonesian EFL learners: Student and teachers' voices. Englisia: Journal of Language, Education, and Humanities, 8(2), 106-119.

Santiana, S., Lesmana, D. S., Marzuki, A. G., \& Erizar, E. (2021, December). An Insight of Anitales Apps Perceived by Digital Storytelling Students. In Proceeding of International Conference on Islamic Education (ICIED) (Vol. 6, No. 1, pp. 23-30). 
Santiana, S., Silvani, D., \& Ruslan. (2021). Optimizing LMS CANVAS for Interactive Online Learning Perceived by the Students. Journal of English Education and Teaching (JEET), 5(4), 529-543.

Santiana, S., Pujasari, R. S., \& Fatimah, A.S. (2021). Blended Learning Strategy: Alternatif Pembelajaran Toefl Bagi Guru-Guru MGMP Non-Bahasa Inggris. Jurnal Inovasi, 1(2020), 144-161. https://ejournal.unib.ac.id/index.php/jurnalinovasi/article/view/15883.

Sugianto, A., \& Ulfah, N. (2020). Construing the challenges and opportunities of intercultural language teaching amid Covid-19 pandemic: English teachers' voices. Journal of English Language Teaching and Linguistics, 5(3), 363-381.

Thornbury, S. (2005). How to Teach Speaking. England: Pearson Education Limited Longman.

Thuy, N, H \& Nga, T, T. (2018). An investigation into Efl Speaking Class Assessment. Accessed on : Wahyuni, S. (2012). Qualitive Research Method: Theory and Practice. Jakarta: Salemba empat

Waugh, D., \& Jolliffe, W. (2008). English 3 - 11: A guide for teachers. Routledge: New York

Whidiayu, S. (2018). Students' Perception on the Use of Video to Assess Performances in Public Speaking Class.

Widodo, H. P. (2017). Constructing and Negotiating Agency and Identity of English Language Learners: Teacher-Learner Driven ESP Materials Development in the Indonesian Secondary School Context. Electronic Journal of Foreign Language Teaching, 14(2).

Yule, G. (1998). The Spoken Language. Annual Review of Applied Linguistics, 10(2), 163-173. 